\title{
Thermal barrier coatings on niobium-based alloys structural materials
}

\author{
V. P. Babak ${ }^{1} \bullet$ V. V. Shchepetov ${ }^{1} \bullet$ T. T. Suprun ${ }^{1} \bullet$ O. V. Kharchenko ${ }^{2} \bullet$ S. D. Kharchenko ${ }^{1}$ \\ 1 - Institute of Engineering Thermophysics of NAS of Ukraine, Kyiv, Ukraine; \\ 2 - National Aviation University, Kyiv, Ukraine
}

Received: 16 September 2019 / Accepted: 25 September 2019

\begin{abstract}
During thermocyclic creep, the properties of a niobium alloy with a two-layer combined coating were studied at a temperature of $1400^{\circ} \mathrm{C}$ in air. A comparison of the data obtained with other coatings is made. The role of the shape and distribution of cracks in the mechanism of strength degradation of coatings is investigated. Consideration of many factors in the formation of the combined coating ensured an increase in its durability of 1.9...8.5 folds depending on the temperature mode of creep.

The applied structural materials do not provide the relevant requirements for the development of modern technology, the need to increase their functionality. Thus, the operational capabilities of nickel alloys, which for decades have provided the aerospace complex, have almost reached the upper limit. One of the actually directions for solving the existing situation is the alternative use of new generation heat-resistant materials for modern highly reliable equipment. For example, the use of niobium-based alloys, the prospect of which is due to their physicomechanical properties than excellent similar products.
\end{abstract}

Keywords: alloy, structure, system, temperature, coatings

\section{Introduction}

The development of coatings on niobium alloys has been the subject of many theoretical and applied studies, in particular, common reference [1-5]. The most used are traditional areas of chemical-thermal treatment, due to the addition of modifying elements such as B, Fe, Be, Cr, Ti, V, Ta, W, Mo [6].

To increase the thermal barrier and thermal fatigue properties, multicomponent diffusion coatings of the Ti-Si system have been developed [7]. It should be noted that the most effective results on the protection of niobium alloys were obtained by the method of vacuum activated diffusion alloying [8]. This method provides a complex coating on niobium. The application of coatings on niobium alloys in liquid metal melts is widely used [9]. Fusible metals with alloying elements are used as transport melts.

The technology of thermocyclic ion nitriding allows new hardening of niobium alloys [10].

To protect niobium alloys, gas thermal plasma spraying is used [11]. The coating of the Si-Ti-Mo system protects niobium from oxidation in the temperature range $1300-1400^{\circ} \mathrm{C}$. There are works on the protection of niobium alloys by vapor deposition (PVD method). Vacuum-plasma deposition applied complex silicide coatings of the $\mathrm{NbSi}_{2}-\mathrm{MoSi}_{2}$ type [12], which withstood more than 10 hours of operation at $1400^{\circ} \mathrm{C}$ in air.

The widespread use of protective coatings prevents a variety of disadvantages.

Thus, experimental tools for determining the properties of coatings are characterized by a large variety and difference in test methods, sample shapes and sizes, test modes, heating and cooling methods. Therefore, it is difficult to compare the results of individual studies. The data on the determination of the properties of coatings are also not comparable due to differences in the design patterns of coatings, the ratio of thicknesses of different layers, differences in application technologies and the method of preliminary surface preparation. An analysis of the work in our country and in the world indicates the relevance of creating protective coatings on niobium alloys. However, an increase in the number of studies and publications does not provide a solution to this complex problem.

The aim of the article is to generalize the experimental data on determining the properties of coatings under thermocyclic creep and long-term strength of a niobium alloy ( $\mathrm{Nb}-\mathrm{Zr}-\mathrm{C}$ type) with a two-layer combined coating at temperatures of $1400^{\circ} \mathrm{C}$ in air and analyze the obtained experimental values with the properties of diffusion silicide coatings, as well as compare their degradation results under conditions creep. 


\section{Methods}

A standardized technique was used for accelerated testing of materials with heat-resistant coatings in air under thermocyclic creep [13].

The technique is implemented on laboratory equipment of the "Schelkunchik" type [14].

Three coatings were tested:

I - silicide composition of Si-Fe-Cr-Ti slip method;

II - borosilicidal composition of Si-B-Ti slip method;

III - a complex coating with a plasma sublayer of molybdenum disilicide $\left(\mathrm{MoSi}_{2}\right)$ with an outer diffusion alloying of the surface layer with elements, the main ones being silicon and boron.

Diffusion alloying was done in vacuum. To study the influence of the stress level during creep, the tests were carried out in the range of $40 \ldots 70 \mathrm{MPa}$.

Temperature test conditions are shown in table 1.

Table 1

Test temperature characteristics

\begin{tabular}{|c|c|c|c|c|c|}
\hline № & Mode & $\begin{array}{c}\text { Maximum } \\
\text { temperature, }{ }^{\circ} \mathrm{C}\end{array}$ & $\begin{array}{c}\text { Minimum } \\
\text { temperature, }{ }^{\circ} \mathrm{C}\end{array}$ & $\begin{array}{c}\text { Time } \\
\text { heating, } \mathrm{s}\end{array}$ & $\begin{array}{c}\text { Time } \\
\text { cooling, } \mathrm{s}\end{array}$ \\
\hline 1 & isothermal & 1400 & - & - & - \\
\hline 2 & thermocyclic & 1400 & 250 & 60 & 60 \\
\hline
\end{tabular}

At each loading mode, at least 3 ... 5 samples were tested. Mathematical processing of experimental data was performed according to standard methods and procedures of mathematical statistics.

\section{Results and Discussion}

When analyzing the results of isothermal and thermocyclic creep, the main attention was paid to the plasmadiffusion coating (III). The results on slip-firing diffusion coatings (I and II) are given in a comparative analysis of the damage to coatings.

During plasma diffusion deposition (III), a multilayer coating and microstructure were formed on the surface of the niobium alloy (Fig. 1,a). The highly porous plasma-sprayed layer of molybdenum silicide has a significant spread in thickness $\left(\mathrm{h}=100 \ldots 350 \mu \mathrm{m}, H_{\mu}^{20}=6880 \mathrm{MPa}\right)$.

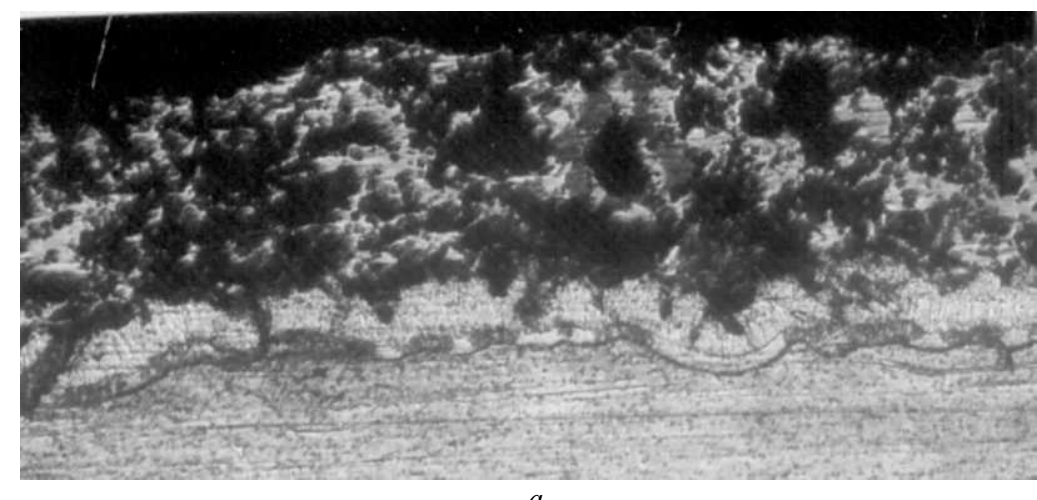

$a$

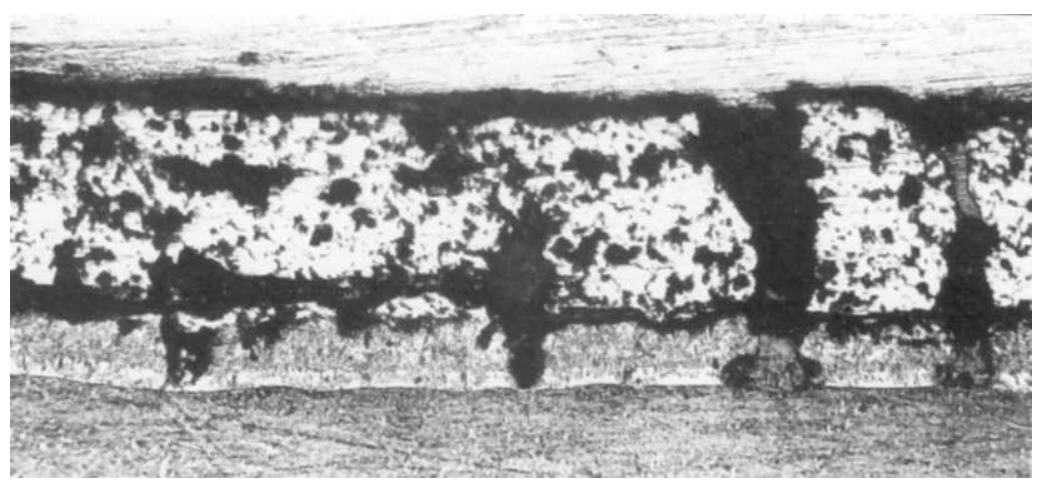

$b$

Fig. 1. Microstructure of the composition of the niobium alloy (III) in the "state as received": $a$-surface prior to testing; $b$ - surface after the test 
When studying the microstructure of the coated (III) samples after testing, it was found that most cracks in the coating originate in the creep process at the interface between the plasma and diffusion layers of the coating (Fig. 1, b). The place of their origin is individual discontinuities in the diffusion layer in the "state as received". The propagation of cracks occurs in the plasma and diffusion layers of the coating. Inhibition of crack growth in the plasma layer occurs due to the rounded nature of the pores and increased ductility of this layer. The growth of cracks deep into the sample is usually inhibited by the boride sublayer.

In [16], the functional dependence of the adhesive strength, residual stresses, and critical deformation of the base on the coating thickness is presented, and the thickness spread of silicide coatings on niobium alloys is also noted.

The thickness of the diffusion layer ranges from $40 \ldots 70$ microns. The nature of the layer follows the microgeometry of the surface of the base on the coating. Due to silicon displacement of boron during directional diffusion of these elements into niobium alloys, the boride diffusion sublayer $\left(\mathrm{NbB}_{2}\right)$ is located under the silicide layer, directly in contact with the base on the coating.

Figure 2 shows the averaged creep curves for the isothermal (1) and thermocyclic (3) test modes.

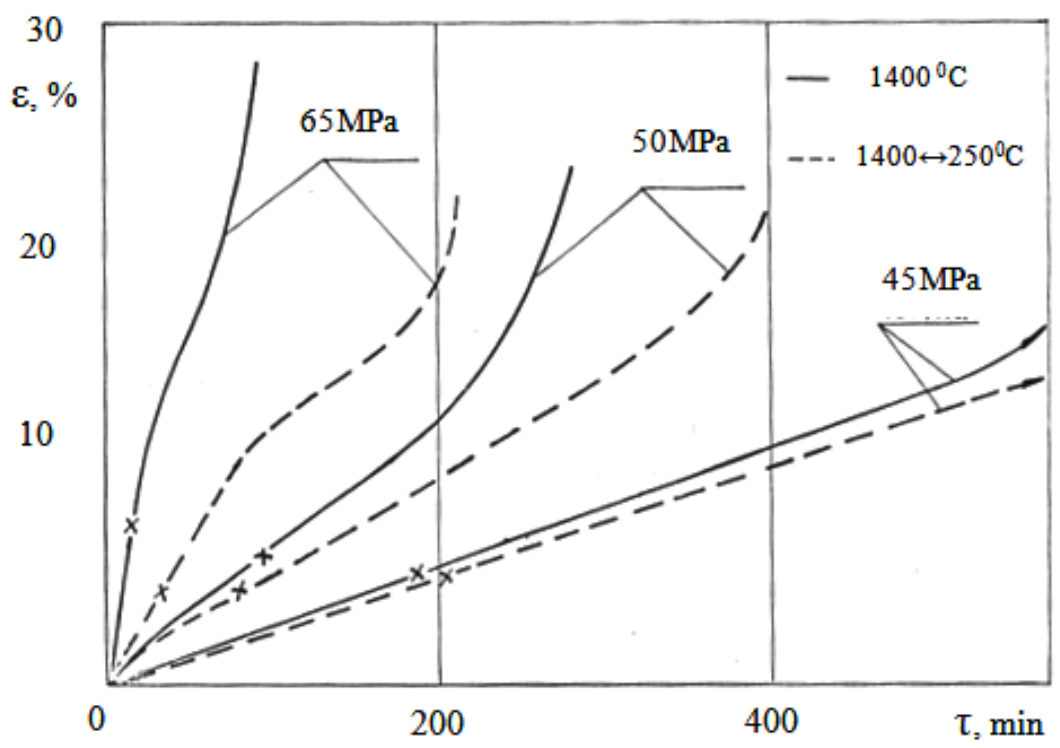

Fig. 2. Averaged creep curves of a niobium alloy ( $\mathrm{Nb}-\mathrm{Zr}-\mathrm{C}$ type) with a plasma-diffusion coating (III) for different test modes

An interesting fact is that the formation of visible cracks on the surface of the coating (indicated by crosses in Fig. 2) occurs long before the complete destruction of the samples. More than $70 \%$ of the durability of the composition depends on cracks in the coating. Moreover, the appearance of cracks on the surface of the coating practically does not affect the nature of the creep of the samples (after the appearance of cracks, the speed of the established creep stage does not change). An important feature of this composition is the higher durability of the samples tested under the thermocyclic mode (3) than under the isothermal mode (1) of tests at voltages above $45 \mathrm{MPa}$. This is also indicated by the relative position of the creep rate curves (Fig. 3) of coated samples (III).

As can be seen from the figures, when tested for less than $600 \ldots 800$ minutes (the number of thermal cycles to failure does not exceed 400), the softening effect of thermal fatigue phenomena does not have time to fully manifest itself. At the same time, the average temperature with isothermal creep is higher than with thermocyclic, which explains the lower durability of the composition in this case. With a large number of tests (loads less than $40 \mathrm{MPa}$ ), thermal fatigue effects begin to prevail in the total accumulation of damage in the composition. The durability of the composition with thermocyclic creep becomes less than with isothermal creep.

As can be seen (Fig. 4), first a network of cracks appears on the surface of the samples. Further, almost all cracks begin to open, which indicates a uniform distribution of deformations along the length of the working part of the sample. Drips of fusible compounds appear on the surface of the coating. When approaching the third creep stage, when the crack opening becomes sufficiently large, the beginning boiling of the indicated melts becomes well noticeable at the mouth of the cracks. The distribution of the compound fills all the cracks almost completely, preventing the penetration of aggressive gas environment deep into coating. In addition, such a melt has reducing properties, inhibiting crack opening. In this case, at elevated temperatures, the multifunctional capabilities of the plastic melt are manifested containing both corrosion and mechanical fracture. An additional study of the kinetics of deformation of the test composition during one heating cycle made it possible to conclude that this effect is most pronounced with thermocyclic creep. 


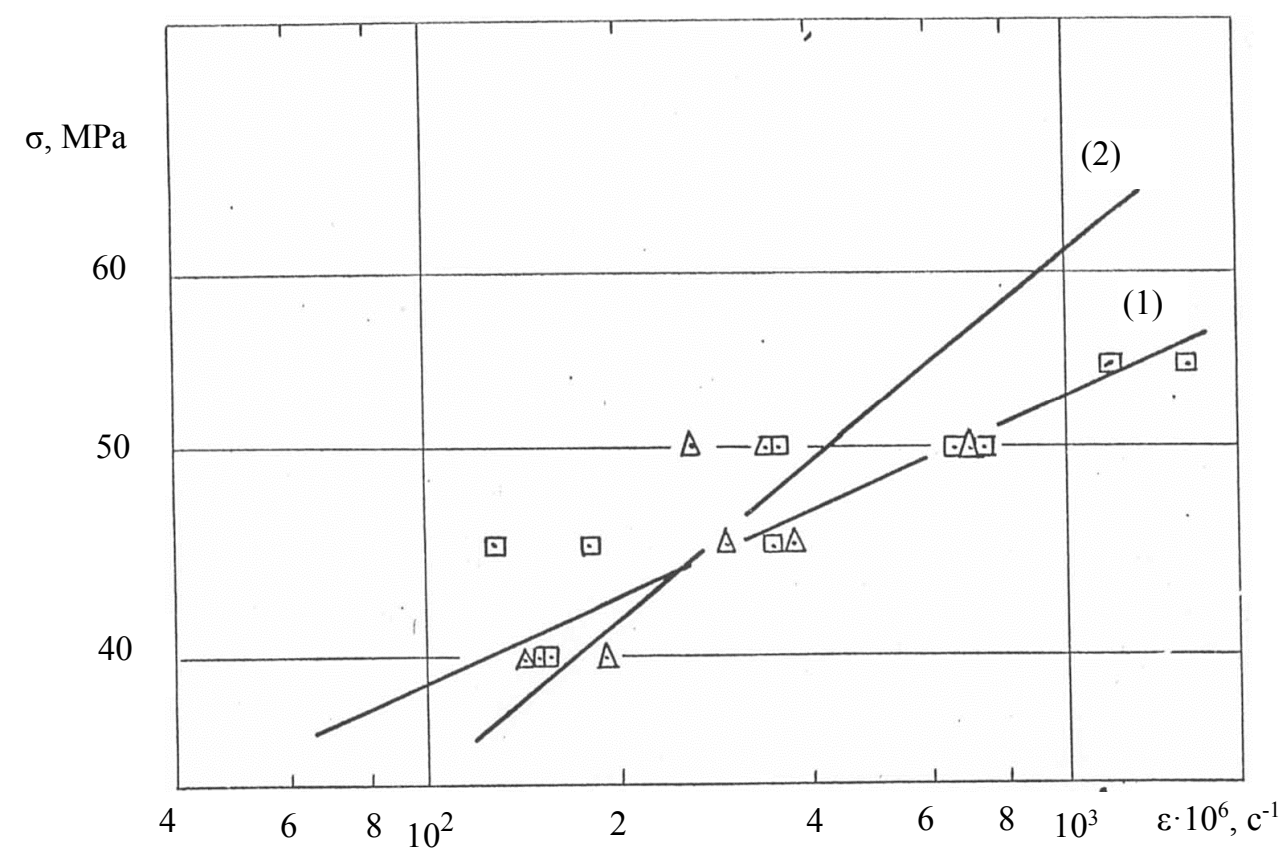

Fig. 3. Dependences of the minimum creep rate on stresses for a niobium alloy ( $\mathrm{Nb}-\mathrm{Zr}-\mathrm{C}$ type) coated (III) under isothermal (1) and thermocyclic (2) test conditions

Compounds that fill cracks melt at temperatures above $1300^{\circ} \mathrm{C}$. At lower temperatures during thermal cycling, these compounds crystallize, resisting crack opening (crack opening during heating is clearly visible from the strain kinetics of the samples shown in Fig. 4).

A few changes in the nature of the destruction of the coating (III) were found when comparing the creep of samples under different loading conditions. The first visible cracks on the surface of the coating under the thermocyclic test mode appear at relative creep strain levels of $4 \ldots 5 \%$, and at isothermal mode (1) $-5 \ldots 7 \%$. In our discussion, such a difference is explained by a change in the ductility of the coating as a function of temperature (in the thermocyclic mode, the average temperature is lower than in the isothermal one). However, a change in the density of cracks appearing in the coating was not detected.

The interaction of atmospheric oxygen usually occurs along the crack channel and causes the predominant oxidation of the silicide layer. This is typical for samples with significant durability. So, almost always this effect is manifested at light loads and, usually, is absent at a value above $50 \mathrm{MPa}$ (Fig. 5, a). Such dominant oxidation causes rounding of the ends of the cracks and a decrease in the stress concentration at the end of the crack compared to cracks with a sharp end.

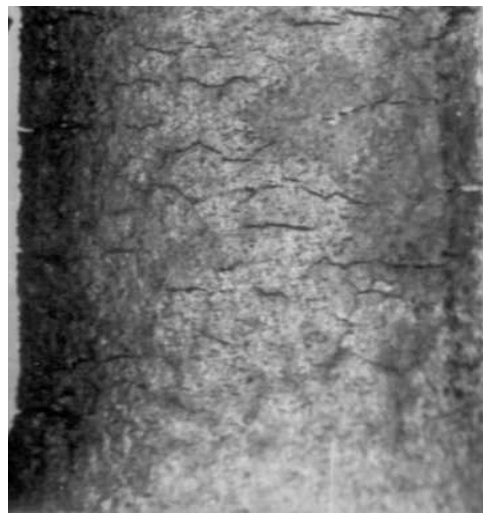

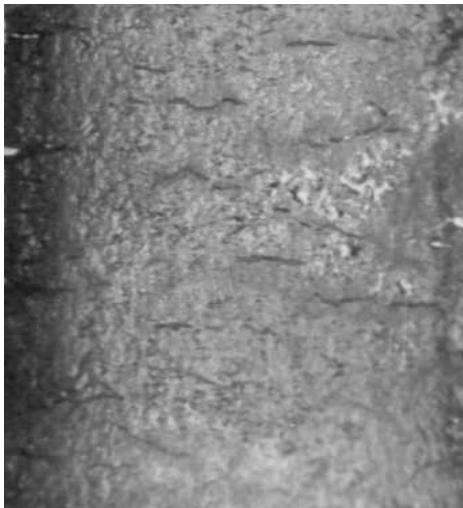

$b$

Fig. 4. Kinetics of deformation of a niobium alloy (Nb-Zr-C type) with III coating during one heating cycle when tested for thermocyclic creep (relative creep strain):

$$
a-4 . . .5 \% ; b-5 . .7 \%
$$

It can be argued that this layer has a restraining effect on the development of the oxidation process deep into the base of the material. 


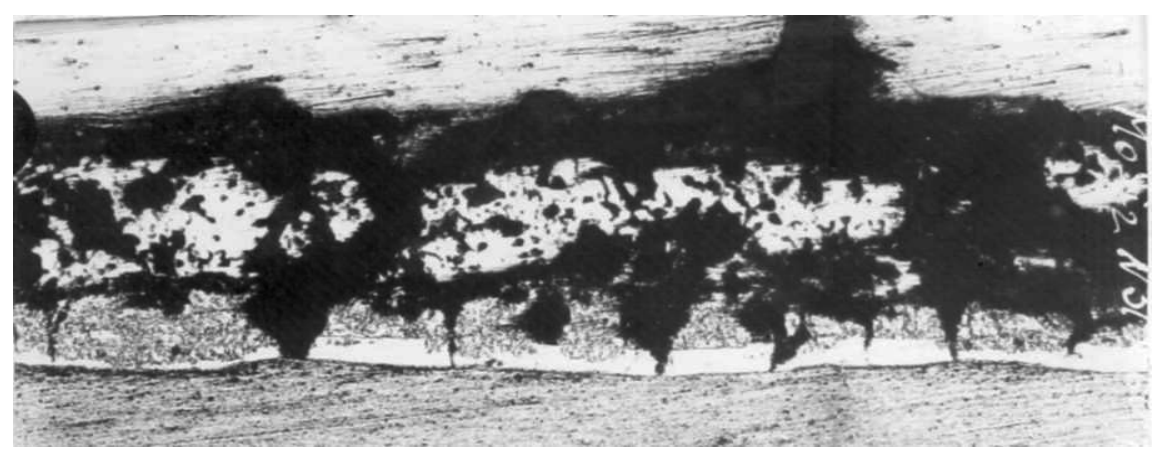

$a$

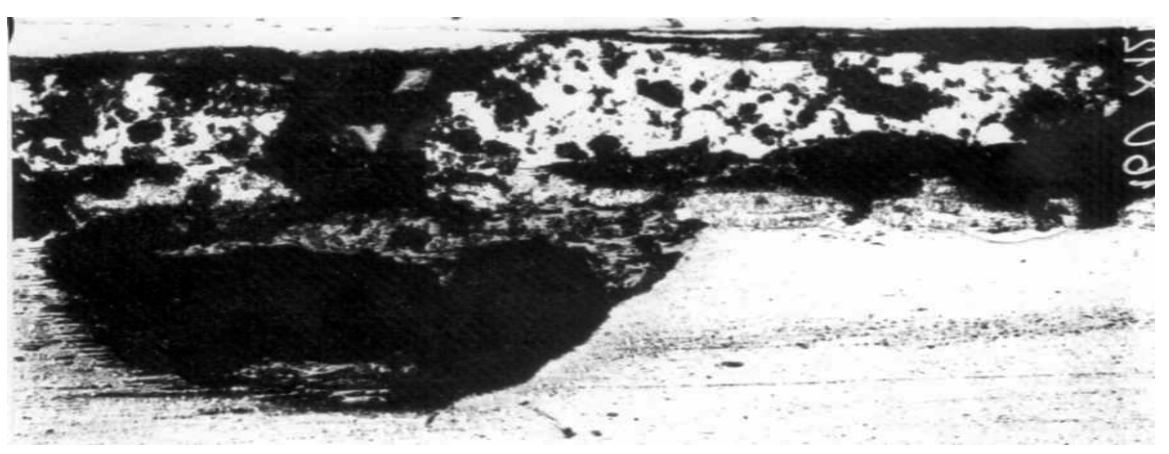

$b$

Fig. 5. The dependence of the propagation of cracks in the composition «Nb-Zr-C $\gg>$ type - plasma-diffusion coating» in the process of creep: $a$ - oxidation of the silicide layer; $b$ - deep umbrella-shaped oxides

The creep dependences of the coated (III) composition were determined and its study was carried out in comparison with compositions of other silicide coatings, type I ( $\mathrm{Si}-\mathrm{Fe}-\mathrm{Cr}-\mathrm{Ti}$ ) and II (Si-B-Ti). According to the research results, we can conclude that the operational properties of the coating (III) are much better. Of particular note is the large increase in deformation during failure in samples with coating (III) compared with coatings (I) and (II): 1.7 ... 1.75-fold and 1.9 ... 2.0-fold.

Since the temperature processes of diffusion saturation during the formation of all three types of coatings are almost the same, we can conclude that the plastic properties of the base material and the compositions under consideration are the same. Therefore, a general increase in the ductility of the composition is achieved by increasing the ductility of the coating (III) itself compared to the other two coatings.

At a load of $50 \mathrm{MPa}$, the composition with the coating (III) has a longer fracture time under the thermocyclic test mode than under isothermal. This composition is qualitatively different from others (I, II). They thermocyclic test mode caused a decrease in durability. With cyclically changing deformations, the durability of the material is a very quickresponse parameter of the surface condition and its defects. Therefore, this strength degradation more depends on the difference in the development of cracks in the compared coatings. The sharp ends of the cracks in the coating (I) differ from the rounded ends in the borosilicidal coating (II). This gives an almost 1.5-fold increase in durability of the composition coated with (II) Nb-B-Si (Ti) compared to (I).

Besides, umbrella-shaped oxides at the ends of cracks in the coating (III) make an even greater decrease in stress concentration.

This reduces the strength degradation of the thermocyclic mode. In addition, cracks in the coating (III) are evenly distributed over the working part of the sample. In other coatings (I, II), single cracks form only in the fracture zone of the sample. The great strength degradation of cracks in coatings (I) and (II) is seen in the creep of the compared compositions. The appearance of cracks in these coatings quickly destroyed the sample (creep transition to the softening stage). At the same time, the formation of cracks on the surface of the coating (III) did not affect the change in creep. As a result of the above features, the composition with coating (III) has a greater durability (1.9-fold and 3.7-fold in isothermal mode; 6.8-fold and 8.5-fold in thermocyclic mode) than niobium alloy (Nb-Zr-C type) with coatings (II) and (I).

\section{Conclusion}

1. The dependences of isothermal and thermocyclic creep of niobium alloy with three coating options at temperatures of $1400 \ldots 250^{\circ} \mathrm{C}$ in air were determined. 
2. The test procedure ensured the reliability of the determination of mechanical properties under the simultaneous action of loads, high temperatures, sudden thermal cycles and an oxidizing environment during radiant heating and noncontact cooling due to focusing of radiant energy.

3. Comparison of extrema: deformations, creep rates and durability under the isothermal and thermocyclic conditions of the three coatings showed the advantage of combined plasma diffusion coatings in comparison with silicide and borosilicidal coatings.

4. The advantage of the combined coating provides an increase in its ductility. Also, thin barrier sublayers, not a continuous coating structure, the presence of fusible compounds, which contribute to the healing of defects in the coating, increase the resistance to corrosion and thermal resistance to destruction of combined coatings. The combination of these properties made it possible to increase the durability in comparison with silicide and borosilicidal coatings under conditions of isothermal creep in air $\left(1400^{\circ} \mathrm{C}, 50 \mathrm{MPa}\right)$ by $1.9 \ldots 3.7$ folds and in conditions of thermocyclic creep $\left(1400 \ldots 250^{\circ} \mathrm{C}, 50 \mathrm{MPa}\right) 6.8 \ldots 8.5$ folds.

\title{
Reference
}

1. Дзядыкевич Ю.В. Защитные покрытия на ниобии, тантале, молибдене и вольфраме для повышения стойкости и высокотемпературному окислению // Порошковая металлургия, 2010. - № 4. - С. 37 - 42.

2. Дзядыкевич Ю.В. Повышение жаростойкости тугоплавких металлов // Неорган. матер. - 2011. - № 11. - С. 1405 1408.

3. Yu Jiadou. Oxidation resistant coatings on refractory metals // Actual Probl. Mod. Mater. Sci.: $1^{\text {St }}$ Russ. Chin. Symp. / Russ. Cent. Constr. and Funct. Mater. - Moscow, Tomsk, 2012. - C. 88 - 89.

4. Babak V.P., Shchepetov V.V. Wear resistance of amorphous-crystalline coatings with solid lubricant // Journal of Friction and Wear, 2017, vol. 38. - P.65 - 70 .

5. Змий В.И., Руденький С.Г., Бредихин М.Ю. и др. Жаростойкие покрытия на ниобии и его сплавах // Порошковая металлургия, 2008, № 3. - С. 23 - 29.

6. $\quad$ Глушко П.И., Змий В.И., Семенов Н.А. и др. Стабильность и жаростойкость силицидных покрытий на тугоплавких металлах. III. Стабильность силицидных покрытий на ниобии в условиях высокотемпературного нагрева на воздухе при 1500-1800 ㅇ // Порошковая металлургия, 2003. - № 3/4. - С. 55 - 59.

7. Adamyan T.A., Kharatyan S.L. On the singularity of high temperature carbidization of niobium // J. Alloys and Compounds, 2010. - № 1 - 2. - C. 418 - 422. https://doi.org/10.1016/j.jallcom.2010.01.154

8. Murakami T., Sasaki S., Ito K. et al. Microstructure of $\mathrm{Nb}$ substrates coated with $\mathrm{Mo}(\mathrm{SiAl})_{2}-\mathrm{Al}_{2} \mathrm{O}_{3}$ composite and B-doped Mo5Siz layer by spark plasma sintering // Intermetallics, 2004. - № 7 -9. - C.749 - 754. https://doi.org/10.1016/j.intermet.2004.02.015

9. Alov N.V. Surface oxidation of metals by oxygen ion bombardment // Nucl. Instrum. and Meth. Phys. Res. B., $2007 .-$ № 1. - C. $337-340$

10. Патент №113934 Украины. Высокотемпературный износостойкий материал; С23С 4/067 / В.П. Бабак, В.В. Щепетов, М.С. Яковлева // Опуб. от 27.03.2017; Бюл. №6.

11. Бухановский В.В., Борисенко В.А., Харченко В.В. и др. Высокотемпературная прочность ниобиевого сплава 5ВМЦ с силицидно-керамическим защитным покрытием. Сообщение 1. Характеристики кратковременной прочности // Проблемы прочности, 2004. - № 2. - С. 119 - 129.

12. Babak V.P., Shchepetov V.V. Increased wear coatings due intrastructural stlf corrtction // Journal of engineering sciences, 2019. №2. - P.11 - 15 .

13. Guille J., Matini L. Microindentation characterization of silicide coatings on niobium and titanium // J. Maters. Sci. Lett., 2016, 7. - № 9. - C. 952 - 954.

14. Thermo-mechanical fatigue of aero-engine turbine blades // Metallurgia, 2014. - № 5. - C. 180.

15. Zhang Y.H., Withers P.J., Fox M.D. et al. Damage mechanisms of coated systems under thermomechanical fatigue // Mater Sci. and Technol., 2009. - № 9. - C. 1031 - 1036.

16. Heidenreich R., Papenburg U., Schäfer R. Prüftechnik für Hochtemperatur - Konstruktionswerkstoff // Mat.-wis. U. Werstofftech, 2014. - № 25. - C. $30-38$.

\section{Термические барьерные покрытия на ниобиевых сплавах структурных материалов}

\section{В. П. Бабак, В. В. Щепетов, Т. Т. Супрун, Е. В. Харченко, С. Д. Харченко}

\begin{abstract}
Аннотация. В проиессе термочиклического ползучести были исследованы свойства ниобиевого сплава с двухслойным комбинированным покрытием при температуре $1400^{\circ} \mathrm{C}$ на воздухе. Проведено сравнение полученных данных с другими покрытиями. Исследована роль формы и распределения трещин в механизме деградации прочности покрытий. Учет многих факторов при формировании комбинированного покрытия обеспечил увеличение его долговечности в $1,9 \ldots 8,5$ раза в зависимости от температурного режима ползучести.
\end{abstract}

Ключевые слова: сплав, структура, система, температура, покрытия 


\title{
Термічні бар'єрні покриття на ніобійових сплавах структурних матеріалів
}

\author{
В. П. Бабак, В. В. Щепетов, Т. Т. Супрун, О. В. Харченко, С. Д. Харченко
}

Анотація. В процесі термоциклічною повзучості були досліджені властивості ніобієві сплаву з двошаровим комбінованим покриттям при температурі $1400^{\circ} \mathrm{C}$ на повітрі. Проведено порівняння отриманих даних 3 іниими покриттями. Досліджено роль форми і розподілу тріщин в механізмі деградації міиності покриттів. Облік багатьох факторів при формуванні комбінованого покриття забезпечив збільшення його довговічності в 1,9 ... 8,5 рази в залежності від температурного режиму повзучості.

Ключевые слова: сплав, структура, система, температура, покрытия

\section{Reference}

1. Dzyadykevich, Yu.V. (2010), Zashchitnye pokrytiya na niobii, tantale, molibdene i vol'frame dlya povysheniya stoikosti i vysokotemperaturnomu okisleniyu, Poroshkovaya metallurgiya, no. 4, pp. $37-42$

2. Dzyadykevich, Yu.V. (2011), "Povyshenie zharostoikosti tugoplavkikh metallov", Neorgan. mater., no. 11, pp. 1405 - 1408.

3. Jiadou, $\mathrm{Yu}$ (2012), "Oxidation resistant coatings on refractory metals", Actual Probl. Mod. Mater. Sci.: $1^{\text {St }}$ Russ. Chin. Symp., Russ. Cent. Constr. and Funct. Mater., Tomsk, Moscow, Russia, pp. $88-89$.

4. Babak, V.P. and Shchepetov, V.V. (2017), Wear resistance of amorphous-crystalline coatings with solid lubricant, Journal of Friction and Wear, vol. 38, pp. $65-70$.

5. Zmii, V.I., Ruden'kii, S.G., Bredikhin, M.Yu. and dr. (2008), Zharostoikie pokrytiya na niobii i ego splavakh, Poroshkovaya metallurgiya, , no. 3. pp. $23-29$.

6. Glushko, P.I., Zmii, V.I., Semenov, N.A. and dr. (2003), "Stabil'nost' i zharostoikost' silitsidnykh pokrytii na tugoplavkikh metallakh. III. Stabil'nost' silitsidnykh pokrytii na niobii v usloviyakh vysokotemperaturnogo nagreva na vozdukhe pri 1500$1800^{\circ}$ S", Poroshkovaya metallurgiya, no. 3/4, pp. $55-59$.

7. Adamyan, T.A. and Kharatyan, S.L. (2010), "On the singularity of high temperature carbidization of niobium", J. Alloys and Compounds, no. $1-2$, pp. 418 - 422, https://doi.org/10.1016/j.jallcom.2010.01.154

8. Murakami, T., Sasaki, S., Ito K. and dr. (2004), "Microstructure of Nb substrates coated with $\mathrm{Mo}\left(\mathrm{SiAl}_{2}\right)_{2}-\mathrm{Al}_{2} \mathrm{O}_{3}$ composite and B-doped $\mathrm{Mo}_{5} \mathrm{Si}_{3}$ layer by spark plasma sintering", Intermetallics, no. 7 - 9, pp. $749-754$. https://doi.org/10.1016/j.intermet.2004.02.015

9. Alov, N.V. (2007), "Surface oxidation of metals by oxygen ion bombardment", Nucl. Instrum. and Meth. Phys. Res. B., no. 1. pp. $337-340$.

10. Babak, V.P., Shchepetov, V.V. and Yakovleva, M.S. (2017), Vysokotemperaturnyi iznosostoikii material; C23C 4/067, Opub. ot 27.03.2017; Byul. №6, Ukraine, Patent №113934.

11. Bukhanovskii, V.V., Borisenko, V.A., Kharchenko, V.V. and dr. (2004), "Vysokotemperaturnaya prochnost' niobievogo splava 5VMTs s silitsidno-keramicheskim zashchitnym pokrytiem. Soobshchenie 1. Kharakteristiki kratkovremennoi prochnosti”, Problemy prochnosti, no. 2, pp. $119-129$.

12. Babak, V.P. and Shchepetov, V.V. (2019), "Increased wear coatings due intrastructural stlf corrtction", Journal of engineering sciences, no. 2. pp.11-15.

13. Guille, J. and Matini, L. (2016), "Microindentation characterization of silicide coatings on niobium and titanium", J. Maters. Sci. Lett., 7. no. 9, pp. $952-954$.

14. Thermo-mechanical fatigue of aero-engine turbine blades (2014), Metallurgia, no. 5, pp. 180.

15. Zhang, Y.H., Withers, P.J., Fox, M.D. and dr. (2009), "Damage mechanisms of coated systems under thermomechanical fatigue", Mater Sci. and Technol., no. 9, pp. 1031 - 1036.

16. Heidenreich, R., Papenburg, U., Schäfer R. (2014), "Prüftechnik für Hochtemperatur - Konstruktionswerkstoff”, Mat.-wis. U. Werstofftech, no. 25, pp. $30-38$. 